\title{
Management Model of Education in Managing Superior Schools in Al-Arief Jambi Islamic Vocational School
}

\author{
Mulyadi \\ STAI Auliaurrasyidin Tembilahan, Indonesia \\ Corresponding author email: mulyadi@stai-tbh.ac.id
}

Abdul Syahid

STAI Auliaurrasyidin Tembilahan, Indonesia

Email:abd.syahid@stai-tbh.ac.id

\author{
M. Ilyas \\ STAI Auliaurrasyidin Tembilahan, Indonesia \\ Email: muhammad.ilyas@stai-tbh.ac.id \\ Kafrawi \\ STAI Auliaurrasyidin Tembilahan, Indonesia \\ Email:kafrawi@stai-tbh.ac.id \\ FahrinaYustiasari Liriwati \\ STAI Auliaurrasyidin Tembilahan, Indonesia \\ Email: fahrina.yustiasari@stai-ac.id
}

\begin{abstract}
This paper's goal was to determine the school management model in realizing excellent superior schools in Islamic Vocational High School Al-Arief Jambi. To understand what model to use, we have chosen a descriptive design type with qualitative analysis under the phenomenology approach and in-depth interpretation to achieve this study question. We use a data collection method with several techniques, including direct observation with field studies, semi-structured interviews, and documentation to get data findings that we believe are valid and reliable. Finally, we can conclude our findings between the management of the implementation of education in Vocational High Schools at the Al-Arief Jambi Islamic Education foundation has been going as expected, such as 1) Educational Plan Sector, 2) Learners Development, 3) Fund Management, 4) Human Resources Sector, 5) Learning facility and Promomis, 6) Public Relations Sector. All of the functions we have mentioned allow significant changes to occur to make the school superior to other schools in Jambi and its surroundings.
\end{abstract}

Keywords---model educational management, superior school, vocational high school.

\section{Introduction}

Understanding education is defined as knowledge of school governance, education management, and teaching, which can be understood as project management of cultural arts. The skills to manage education and teaching programs to achieve optimal goals towards productive results require a variety of skills and sincerity. Therefore, the management of education requires skills and knowledge about a variety of useful management models, which are based on a multiple approach perspective and academic and managerial management of human resources, time resources, facilities, large funds, administrative systems, and other financial management. 
The aim of maximizing educational outcomes encourages parties to work cooperatively to systematically mobilize superior and profitable managerial and financial benefits and sustainability for educational cooperation. Likewise, it impacts work culture and psychology on the continuity of desires that are sometimes difficult to fulfill. This often requires humans to function like robots to move mechanically, only controlled by other parties. It should not be that humans do not lose self-control following their human nature to become creatures that can act according to their will and are free to make choices and have full rights of their own, which must be recognized properly and with dignity. Humans should not be alienated from their existence when the flow of interaction between humans is increasingly reduced in terms of integrity and existence (Wahab, 2011; Aslan et al., 2020; Hifza et al., 2020; Dewi et al., 2020; Oskar Hutagaluh, 2019; Hutagaluh et al., 2020).

Leadership can influence others and has managerial authority (Decenzo \& Robbins, 1999; Robbins et al., 2012; Hutagaluh et al., 2020). From both the component point of view, the person manages certain operations and processes in planning the staff hard task effectively together successfully, as said by Henri Fayol, trying to explain the four-step development planning, organizing, commanding, codification, and control. These functions are now summarized into four components, first preparation, second arrangement, third-leading, fourth trying to control. (Hifza, 2020). Of the four managerial utilities needed to gain the target and outcomes that were planned at the institution. From the previous issues, This could be perceived which the leadership of academic achievement is an organizational exercise that is a daily routine of recording, publicizing, coordinating communications with all elements, and monitoring. A manager is effectively somebody who can affect the actions of others in his task by using authority. The larger the number of forms of electricity accessible to the president, and according to Stoner, the greater the possibility for strong leadership (Alimo-Metcalfe \& Lawler, 2001). Gibson, Ivancevich, and Lehman define leadership as a process in which an individual impacts others to achieve the desired goals without increasing. Organizational culture is an opportunity to use impact without exploitation to encourage the person to improve some goals (Bertocci, 2009).

Depending on the above style of entrepreneurship, the ruling is the system of affecting anyone out of coercion, communicating the visionary goal with going to turn it into activity, and empowering others, while also being accountable, disperse mental stimulation and concern, likability, and recognizing that view to serve the overall goals set. Transformational leadership has been a common transformational leadership over the last few years. This is what Stephen said of transactional leadership. Representatives that enhance and encourage (transform) subordinates to accomplish outstanding performance. The current leader seeks to bring about a degree of effort and employee implementation is far intelligent than others and provides the supervisor with the ability to understand previous opinions and views (Robbins, 1994).

Interpretation of Flavia Cavazotte's managerial transformation. Valter Moreno and Jane Bernado have demonstrated and followed leadership styles. The leadership style was developed based on two classic points of view, and the term leadership style was coined. Discussing such representatives as change agents who arouse and reshape the belief systems of followers. Discussing such representatives as change agents that arouse and reshape followers' belief systems. These managers provide a visionary insight and create empathetic relationships with followers. The other's knowledge and believing in the highest authority is increasing, underneath their best interest. Such leaders' characteristics were also split into four aspects: idealized influence, individualized consideration, academic stimulation, and individualized consideration (Cavazotte et al., 2013).

The same can be shown above that a strong leader is a strong figure and has a crucial role and strategy in efforts to put the institution to its objectives. A transformational leader will be able to align long fantasies with those of his superior officers and enhance staff's same needs to a greater level than they'd like. The leader must be able to impact his supporters to achieve organizational objectives. Beginning with both the findings of the studies at the Al-Arief Jambi Islamic Technical College, the investigator saw the investigator's mission and vision.

\section{Research Methodology}

To understand the typical management carried out so that the Al-Arief Jambi Islamic Vocational High School has proven successful in becoming one of the best schools in Jambi province, we have carried out a series of data collection which includes semi-structured interviews with several school boards and leaders, field observations and documentation of various documents (Creswell \& Creswell, 2017). Then we continue with in-depth analysis, looking for understanding to ensure that the data we analyze under the phenomenology approach has answered this question by adhering to the principles of validity and reliability of the findings under the recommended qualitative design research guidelines John Creswell. 
These same documents analyzed in this mini-research were also college position books, student conduct publications, student attendance programs, and photos of school programs at Al-Arief Jambi Islamic High School. (Sukardjo, 2004). The headmaster, deputy of the school system, graduate admissions, facilities, and infrastructure, are also references for conversation data. The data collected will be analyzed and authenticated using maneuvering to validate the results of the studies. The phases of such research are 1) the post-stage, 2) this same stage of field research, 3) this same stage of preparing the article.

\section{Result and Discussion}

\section{Social transformation governance}

Available evidence of scientists in terms of consistency at the Al-Arief Islamic Vocational High school Jambi, a leadership change tends to occur through jobs programs that are considered a part of the college's success in implementing the school's vision and mission, academic leadership can inspire staff and nurture team leaders so that an institution's objectives and goals can be easily done. A transactional leader is becoming a common inspirational leader in the last few years. It is indeed, as Stephen stated, different policymakers with collaborators. Rulers who improve and encourage exceptional results for subordinates. Management aims to produce a much better level of effort and employee performance than that. The ability to query existing views and opinions retained by the leader and to instill them under him.

Predicated from the above concepts, what is implied by transformational leaders of the headmaster is "a commander who would bring forth the response in the body of a school, coordinated by the value systems which have been set by encouraging the rest of the school society thru the direct contact. Such that the adherents can task with energy and focus. So that learning can be revolutionary. Management has measures; visionary, show respect, encourage superiors' efficiency, synchronize the workplace environment, trick subordinates, act mostly on a system of values, and increase the eagerness to cope with difficult issues through a continuing process (Hifza et al., 2020).

In school administration, this same Agency's system helps guide and directs school work execution to achieve the academic goals and school objectives set. As a man in charge of teaching education for people and staff training, as a service tech, The education system conducts organizational activities, i.e., planning, student attendance initiatives, coordinating, local college tasks, behaving, the whole education department, and guidance (Sagala, 2008). The strategy is characterized as the use, institution, mobilizing of school funds, Healthcare infrastructure efficiently and effectively. Muslim Social work High School Al-Arief Jambi is renowned for its good schools, which were presently getting rebranded underneath the Schooling Law and Collaboration Educational Program

\section{School management}

Researcher's observation data in facing global challenges at the Al-Arief Jambi Islamic representatives prepared career training schools, team leaders, learners, and parents in the educational setting, as the person in jobs of educating major for people and American schools, to pay attention to development problems for at least another individual. Rulers get school administration's smooth functioning, such as preparation, student attendance initiatives, arranging, local college tasks, acting, and managing the overall public schools (Schoonenboom, 2014; Demir \& Kocabaş, 2010). From the researcher's point of view, the governance here is a leadership style framework. Transformational leadership helps audiences to do what remains to be improved to attain the required results. Furthermore, a transformational leadership style that will enforce school management is the Great film transformational leadership used in this study.

\section{Education core system}

A primary substratum for school systems in instructional management. Under Education Act Law No. 20 of 2003, the plan is to collect proposed changes and contracts on materials and methods for goals, equipment, and priorities for use as policy guidelines for learning activities to achieve specific education success. At a minimal level, the instructional syllabus can be altered to serve teachers of fruitful and knowledge leadership styles, such as Making plans, Advancement, Delivery, and Assessment, which form a solid procedure known as this same instructional cycle, which could be used in curriculum design behavior. Islamic Special education Junior High Al-Arief Jambi carried out the Education system in 2013. 
The learning environment was conducted out in 2013 due to various difficulties (Aslan, 2016; Aslan, 2017; Aslan, 2019; Aslan \& Wahyudin, 2020). Inbuilt issues relate to the requirements of schooling alluded to in the 8 Statewide Educational Outcomes and variables for both the Indonesian population's advancement. Outer difficulties are linked to new progress.

As the spearhead, the instructor might even become the frontline and front security officer in curriculum implementation in the curriculum 2013. It's doesn't matter how successful the curriculum is. Believe that the running teacher does not have good skills. The syllabus will then not run excellently. This same readiness of teachers will be a determinant in implementing the new education system. Undoubtedly, no matter what comprehensive the central planning (curriculum) is, the performance and training of schools in the lesson plan will depend on anything in the field. This same idea of educator's preparedness is the capability and eagerness of the instructor to guide their conduct. Educators should always try to adapt to the fresh govt curriculum. Consequently. It is important to consider teachers' expertise and preparedness in teaching the above laws and standards to update the school program (tends to result in an interview with both the Deputy Director of Curriculum).

\section{Student organization}

The components of the commencement of teaching programs are students or educators. Learners are members of the community who, through the learning experience, through the accessible active learning, seeking to enhance their level of incentive and level of school. There have been at least 3 important tasks for leadership development that need to be taken into consideration in achieving educational goals, which include new students, as well as activities for teaching development. Advice and supervisory assistance are conducted by holding hands with the instructor, reading the holy verses of al-Qur'an before actually approaching the lesson.

\section{Governance of officers}

Organizational culture, in specific, is the highest honor that pays attention to people in their friendships. Employee communication can be defined as the science and art of planning, organizing, trying to direct, and attempting to control to function efficiently with job performance.

\section{Financial stability}

Money planning at Vocational High school Islam Al-Arief Jambi corresponds to how school systems obtain funds, average price, document school financial services, direct and monitor funds, drawing on discussions with the finance office. Seeking funding at Islam Al-Arief Jambi Tech College The source of money arrives from the School Board's executive order, and the national budget is frequently used for education systems. Consequently, in any use of finance, whether it be from govt, society, and other sources, it is important to provide care and attention to accountability variables from all educational communities mainly internal personnel.

\section{Facilities and infrastructure management}

The Al-Arief Jambi Islamic Career training School, seen on the supporting documents data, such as constructions, classes, desks, chairs, and educational materials and communications, is among the schools that met this outstanding school. The health and hygiene leadership of the school is obtained from the service providers. So, learners aren't involved in cleaning the construction.

\section{Prototype of regulation}

The Islamic Vocational High school Al-Arief Jambi is said to be a superior education mostly based on research findings since it can be increased and handled and necessary with guiding all the elements to gain highly skilled graduate outcomes than other college grads. Two standards, namely skill, and loyalty, are met and are always revised and continuously established (Ahmad, 2015). It can contribute significantly to the excellence of a school, which can only be attained through a student's excellence. It is said that it is superior. Islamic Vocational High School Al-Arief Jambi meets the following requirements if the criteria are met: 


\section{Governance of school systems}

School management is required to achieve superior school administration goals, as per the conditions and situations wherein the school is held (Arffa et al., 1998; Iserbyt et al., 2014). A headmaster or figurehead has to look at close attention to school planning's non-official components: the particular dimension and the invisible aspect. Educational quality indicators need to be understood and developed.

These factors have been met by the ten indicators of the outstanding school criteria at Muslim Vocational High School Al-Arief Jambi. Students learn well through first metrics, conducive environment and facilities, and facilities. Good and adequate services help the teaching method. First, a quiet atmosphere for studying. Merely tidy. To end up making the environment a pleasant school trying to set, beautiful and cool. Second, the teaching process is for the delivery of learning activities. third, instructors' focused education makes students learn extra quickly. Fifth, the instructor, is smarter when he through enough. So learners are not ready to receive the material: Fifth, higher management, higher management. Sixth, good learning is carried out by teachers of Islamic Vocational School AlArief Jambi in the reality of times. It ensures those the educators of all-cause lesson fulfills his teaching duties. Next seventh, the evaluation of each subject carried out by the teacher has met the learning objectives. Three aspects, cognitive, affective, and psychomotor, of learner objectives. Eighth, the teacher's assignment of the gem lesson was carried out well, ninth in dealing with student problems. Teachers can solve both individual and individual issues and in groups. Teacher learning has used multimedia in the transmission.

In the consolidation of integrated education quality management in the world of competition, the strategies and approaches used must start from educational institutions' position as service institutions or, in other words, become industries that train and prepare quality human resources. Likewise, the quality control of Islamic Vocational High School Al-Arief Jambi as a whole has met competitive indicators, namely through three-stage indicators towards continuous improvement and continuity of quality competitiveness (Yang, 2015; Top et al., 2012; Rusman \& Lukman, 2017). Full attention to clients, internal and external clients, process coaching, and total participation are the three steps to continuous improvement.

Excellence School Criteria A school can be said to be a higher school if it has three main elements that need to be met to become a higher school, namely:

\section{Information}

The knowledge of the nervous system Intelligence and transformational leadership could be seen from quality input. As well, during the launch of local learners, the spirituality of prospective applicants must be quantifiable. Accordingly. The new college test method should analyze all three intellectual ability components or even evaluate differentiated instruction. The implementation of the marketing pupil selection test is to accept or reject those other learners and explore the level of school intelligence. It could be used as a criterion for formulating the promotional opportunity and even evaluating the goal or orientation of higher education, with information on these students' level of intellect (Ghufron, 2017; Widodo, 2017).

\section{Procedure}

Top educational institutions should at least listen to the quality of students, internet ecosystem, curricula, learning methods, extracurricular activities initiatives, and cooperative networks in the teaching-learning activities, which include:

a) Skilled abilities for instructors;

b) Effective teaching helps us to make an outstanding academic establishment. First, topic mastery professionalism. Second, training basics. Third, mentorship skills. Fourth, pupil interpersonal skills. Fifth, evaluation skill sets;

c) Educational facilities. Referenced schools should be provided with advanced equipment and services to satisfy learners in perfecting science and technology;

d) Curriculum. The international standard curriculum does not have to be used by featured schools. The National Curriculum is quite good with various improvements according to students' development needs;

e) Methods of learning. Starred school systems should use teaching styles that make learners active and innovative, followed by independence to convey their opinions.

f) Starred schools should have a sequence of school activities that can support all abilities, priorities, and intellect. Network for collaboration. Leading schools have good cooperation networks with different agencies, 
particularly education-related agencies and skills development agencies. Collaboration with different agencies will make it easier for students to apply to different life sectors and understand them.

Outcomes

Islamic Social work High School Al-Arief Jambi Education contribution, which includes human capital, had also fulfilled the conditions as just an outstanding college based on data taken based on the education organization culture. 65percent of everyone's learning has magisteriums, the number of educators and school personnel. According to the curriculum, the teacher is professionally competent in the standard of the learning process, a conducive learning space, using the correct learning method. The education system also held after school programs among both schools than in the arts and cooperated with the tourist destination. The education system is the accomplishment of locally and nationally learners, alma mater of the Islamic Vocational High school Al-Arief Jambi, and Jambi Sriwijaya College trying to enter public colleges such as Stated Islamic University of Jakarta Syarif Hidayatullah, Public Islamic higher Education of Sulthan Thaha Saifuddin in Jambi, many more and registered as government employees, regional part-time workers, and business owners.

\section{Conclusion}

An important, superior school is the management application and transparent management at Al-Arief Jambi Islamic Vocational School. The more sophisticated and rapid the development of education, the more active the leadership that works in education has an important role in addressing global challenges. Rulers and learners have to start preparing themself, concerning foreign assets, who have to be of excellent quality to pay attention to difficulties. A Transformation Leadership Model is the leadership model applied at the Al-Arief Jambi Islamic Vocational School. Transformative leadership; idealized influence, motivation for inspiration, intellectual stimulus, and individualized consideration will bring about future changes.

\section{Acknowledgments}

I would like to thank all of my co-authors for their support during the project preparation to completion. Then my appreciation to my colleagues who always share ideas and enthusiasm in motivating me.

\section{References}

Ahmad, K. B. (2015). Educational practice: lessons to be learned from madrasah and religious schools in contemporary Southeast Asia. Indonesian Journal of Islam and Muslim Societies, 5(1), 29-48.

Alimo-Metcalfe, B., \& Lawler, J. (2001). Leadership development in UK companies at the beginning of the twenty-first century. Journal of Management in Medicine.

Arffa, S., Lovell, M., Podell, K., \& Goldberg, E. (1998). Wisconsin Card Sorting Test performance in above average and superior school children: Relationship to intelligence and age. Archives of Clinical Neuropsychology, 13(8), 713-720. https://doi.org/10.1016/S0887-6177(98)00007-9

Aslan, A. (2016). Kurikulum Pendidikan Vs Kurikulum Sinetron. Khazanah: Jurnal Studi Islam dan Humaniora, 14(2), 135-148.

Aslan, A. (2017). Strategi Pembelajaran Dalam "Go Sport” Kurikulum Pendidikan Karakter. Madinah: Jurnal Studi Islam, 4(1), 10-19.

Aslan, A. (2019). Hidden Curriculum.

Aslan, A., \& Wahyudin, W. (2020). Kurikulum dalam Tantangan Perubahan.

Aslan, A., Silvia, S., Nugroho, B. S., Ramli, M., \& Rusiadi, R. (2020). Teacher's Leadership Teaching Strategy Supporting Student Learning During The COVID-19 Disruption. Nidhomul Haq: Jurnal Manajemen Pendidikan Islam, 5(3), 321-333.

Bertocci, D. I. (2009). Leadership in organizations: There is a difference between leaders and managers. University Press of America.

Cavazotte, F., Moreno, V., \& Bernardo, J. (2013). Transformational leaders and work performance: The

Creswell, J. W., \& Creswell, J. D. (2017). Research design: Qualitative, quantitative, and mixed methods approaches. Sage publications.

DeCenzo, D. A., \& Robbins, S. P. (1999). Human Resource Management. 6. vydání. 
Demir, C., \& Kocabaş, İ. (2010). Project management maturity model (PMMM) in educational organizations. Procedia-Social and Behavioral 1641-1645. https://doi.org/10.1016/j.sbspro.2010.12.379

Dewi, N. C., Aslan, A., \& Suhardi, M. (2020). Gaya Kepemimpinan Kepala Sekolah Taman Kanak-Kanak. JMSP (Jurnal Manajemen dan Supervisi Pendidikan), 4(2), 159-164.

Ghufron, A. (2017). Pengembangan Pembelajaran Berbasis Nilai-Nilai Budaya Yogyakarta Di Sekolah Dasar. Cakrawala Pendidikan, (2), 81677.

Hifza, A. (2020, June). The Model of Competitive Advantage Development in Private Islamic Education Institutions. In BASA 2019: Proceedings of the Third International Seminar on Recent Language, Literature, and Local Culture Studies, BASA, 20-21 September 2019, Surakarta, Central Java, Indonesia (p. 205). European Alliance for Innovation.

Hifza, H., Suhardi, M., Aslan, A., \& Ekasari, S. (2020). Kepemimpinan Pendidikan Islam Dalam Perspektif Interdisipliner. NidhomulHaq: Jurnal ManajemenPendidikan Islam, 5(1), 46-61.

Hifza, J., Palapa, A., \& Maskur, A. (2020). The Strategic Foundation for Competitive Excellent Development in Integrated Islamic Primary Schools in Indonesia.

Hutagaluh, O., Aslan, P. P., \& Mulyono, A. W. S. S. (2020). Situational Leadership On Islamic Education. IJGIE (International Journal of Graduate of Islamic Education), 1(1), 1-7.

Iserbyt, P., Charlier, N., \& Mols, L. (2014). Learning basic life support (BLS) with tablet PCs in reciprocal learning at school: are videos superior to pictures? A randomized controlled trial. Resuscitation, 85(6), 809-813. https://doi.org/10.1016/j.resuscitation.2014.01.018

Oskar Hutagaluh, A. (2019). Pemimpin Dan Pengaruh Geo Politik Terhadap Lahirnya Sumber Daya Manusia Yang Berkarakter. Jurnal Studi Islam Lintas Negara (Journal of Cross Border Islamic Studies), 1(2), 23-29.

Robbins, S. P. (1994). Teori Organisasi: Struktur. Desain dan Aplikasi, Terjemahan Jusuf Udaya, PT Arcan, Jakarta.

Robbins, S. P., Judge, T. A., \& Hasham, E. S. (2012). Organizational Behavior (Arab World Edition). Pearson Education, Limited.

Rusman, R., \& Lukman, L. (2017). The Implementation 2013 of Curriculum in Vocational School a Study on "Best Practices" Done by Vocational School Teachers in Planning, Implementing, and Evaluating the Curriculum. International Research Journal of Engineering, IT and Scientific Research, 3(2), 41-49.

Sagala, S. (2008). Silabus Sebagai Landasan Pelaksanaan dan Pengembangan Pembelajaran Bagi Guru Yang Profesional. Jurnal Tabularasa, 5(1), 11-22.

Schoonenboom, J. (2014). Using an adapted, task-level technology acceptance model to explain why instructors in higher education intend to use some learning management system tools more than others. Computers \& Education, 71, 247-256. https://doi.org/10.1016/j.compedu.2013.09.016

Sukardjo, M. (2004). Metode Penelitian Pendidikan. Rineka Cipta, Jakarta.

Top, S., Çolakoğlu, N., \& Dilek, S. (2012). Evaluating entrepreneurship intentions of vocational high school pupils based on self-efficacy concept. Procedia-Social and Behavioral Sciences, 58, 934-943. https://doi.org/10.1016/j.sbspro.2012.09.1072

Wahab, A. A. (2011). Anatomi Organisasi dan Kepemimpinan Pendidikan [Anatomy of the Organization and Educational Leadership].

Widodo, H. (2017). Manajemen Perubahan Budaya Sekolah. Manageria: Jurnal Manajemen Pendidikan Islam, 2(2), 287-306.

Yang, Y. T. C. (2015). Virtual CEOs: A blended approach to digital gaming for enhancing higher order thinking and academic achievement among vocational high school students. Computers \& Education, 81, 281-295. https://doi.org/10.1016/j.compedu.2014.10.004 